\title{
Use of human surplus biospecimens in research: a survey from a cancer centre
}

M. Al-Hussaini' and A. Abu-Hmaidan²

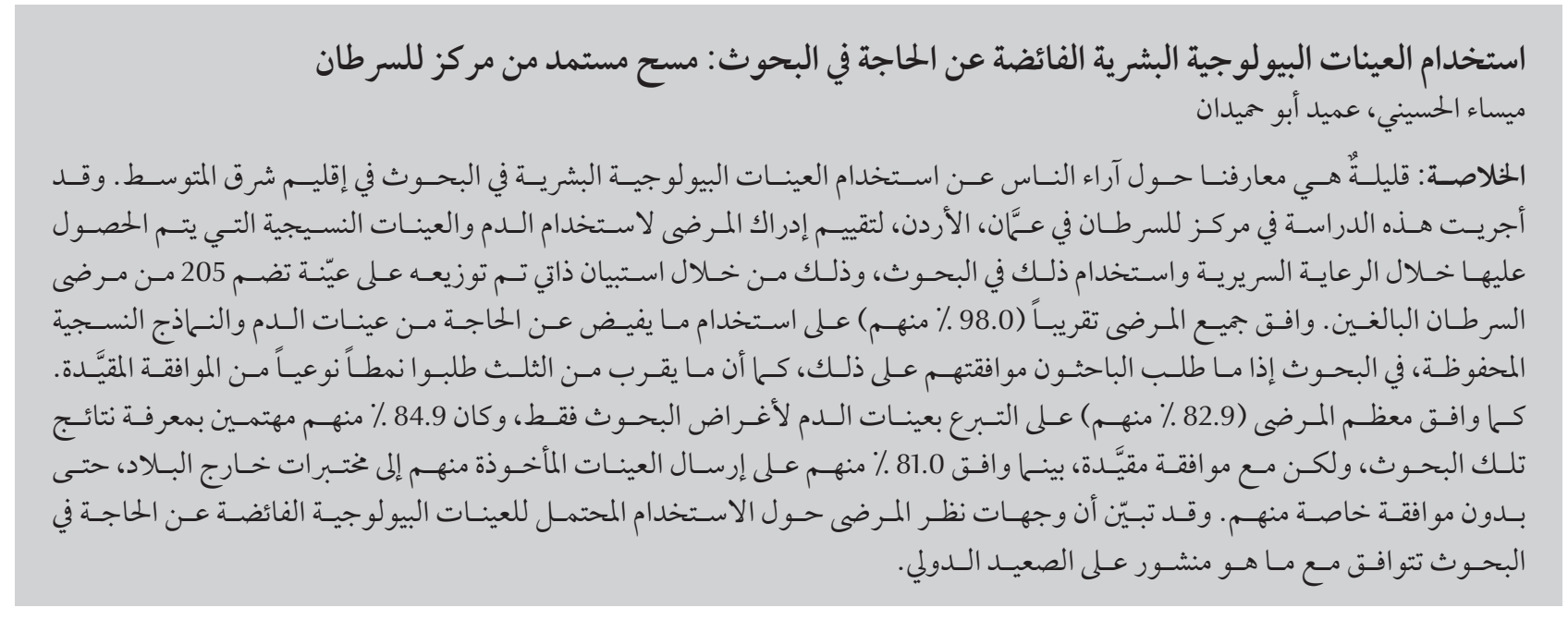

ABSTRACT Little is known about the public's views on the use of human biospecimens for research in the Eastern Mediterranean Region. A study at a cancer centre in Amman, Jordan, assessed patients' perceptions about the use of blood and tissue samples obtained during clinical care and the use of these in research. A self-administered questionnaire was distributed to a sample of 205 adult cancer patients. Almost all patients (98.0\%) accepted the use of their surplus blood samples and archived tissue in research if they consented, with about one-third requesting a specific opt-in consent. Most patients (82.9\%) also agreed to donate a blood sample for research purposes only, $84.9 \%$ were interested to know the results of that research, but with a specific opt-in consent, and $81.0 \%$ accepted sending their samples to research laboratories abroad, even without specific consent. Patients' views on the potential use of the surplus biospecimens in research were largely concordant with the international literature.

Utilisation d'échantillons biologiques humains excédentaires en recherche : une enquête dans un centre anticancer

RÉSUMÉ II existe peu d'informations sur l'opinion du public quant à l'utilisation d'échantillons biologiques humains pour la recherche dans la Région de la Méditerranée orientale. Une étude menée dans un centre anticancer à Amman (Jordanie) a évalué les perceptions des patients concernant l'utilisation des échantillons de sang et de tissu recueillis pendant des soins cliniques et leur utilisation pour la recherche. Un autoquestionnaire a été distribué à un échantillon de 205 patients adultes atteints de cancer. Presque tous les patients (98,0 \%) acceptaient l'utilisation des échantillons de sang et de tissus excédentaires conservés pour la recherche, après leur consentement, et environ un tiers exigeait une demande de consentement spécifique. La plupart des patients $(82,9 \%)$ consentaient également à faire un don de sang à des fins de recherche uniquement, tandis que 84,9\% souhaitaient connaître les résultats de cette recherche après un consentement spécifique, et 81,0 \% acceptaient que leurs échantillons soient envoyés à des laboratoires de recherche à l'étranger, même sans consentement spécifique. Le point de vue des patients sur l'utilisation potentielle des échantillons biologiques excédentaires pour la recherche concordait en grande partie avec les points de vue présentés dans la littérature internationale.

${ }^{7}$ Department of Pathology and Laboratory Medicine; ${ }^{2}$ Clinical Research and Cancer Registry Office, King Hussein Cancer Centre, Amman, Jordan (Correspondence to M. Al-Hussaini: mhussaini@khcc.jo).

Received: 22/05/13; accepted: 28/10/13 


\section{Introduction}

Human biospecimens constitute a valuable resource for different types of basic and clinical research (1), and surplus blood and archived tissue samples are useful for teaching, audit and quality control in laboratories (2). However, when the primary purpose of biospecimen collection and tissue archiving is clinical care, patients are generally not informed of the potential use of leftover biospecimens in research, and specific consent addressing this issue may not have been obtained at the time of specimen collection. Although policies, frameworks and legislations regulating the use of biospecimens in research have been introduced in many countries to overcome potential conflicts (3-8), such regulations are generally lacking in developing countries (9). Internationally unified guidelines regulating the use of biospecimens in research are urgently needed (10).

A search of the medical literature revealed a scarcity of publications in which public or patients' views on the use of human biospecimens for research have been evaluated in the Region. Most Saudi patients surveyed in one centre agreed to the use of leftover samples in research, without (49\%) or with (37\%) consent, with only $14 \%$ objecting (11). Many Egyptians surveyed did not favour the donation of blood samples for research and were hesitant to have their blood samples donated for genetic research or exported outside the Arab region for research purposes (12). In a study from Morocco, inconsistencies were found between laboratories in obtaining informed consent from patients when using their samples in research (13). More recently Ahram et al. explored the attitude of a large cohort (>3000) of Jordanians towards biobanks, a concept which was positively accepted by a majority of respondents (14).

At the King Hussein Cancer Centre in Amman, Jordan, tissue paraffin blocks are archived at the pathology department almost exclusively for clinical care, while blood samples and other biological specimens are disposed of once the requested test is completed. Lately an apparent increase in the use of archived tissue and other surplus biospecimens in research has been noted. Although a national clinical research law came into effect a few years ago (15), nationwide regulation on the use of surplus biospecimens is still lacking. The local institutional review board/ethics committee tries to operate in accordance with international regulations. It demands anonymization, or at least coding of specimens, before granting approval for their use in research. For any prospective collection of blood or tissue specimens primarily for research purposes, and/ or when sending specimens for external laboratories for further testing is part of a collaborative national/international research, obtaining specific consent from the concerned patients is mandated.

The views of our patients on the potential use of their specimens in research have never been studied. Our aim was 3-fold: to assess patients' awareness about the final destination of blood specimens and tissues obtained during the course of clinical care, once this is completed; to explore patients' perceptions and any potential obstacles to the use of surplus blood and archived tissue in research; and to compare the results with the international literature.

\section{Methods}

\section{Sample}

This was a cross-sectional study over a 2-week period (3 April to 14 April 2010). All patients attending the adult chemotherapy outpatient clinic at King Hussein Cancer Centre were approached and those who agreed to participate in the study were recruited and asked to give informed consent. The questionnaire was anonymous, so that identifiers such as names, hospital numbers or national identity numbers were not collected.

\section{Data collection}

A questionnaire was developed by the investigators in English. It consisted of 31 questions divided into 5 parts: demographic data (4 questions); patients' previous experience of medical research (6 questions); assessment of patients' awareness of the destination of surplus blood (5 questions) and tissue specimens (8 questions) acquired during the course of routine clinical care; and patients' perceptions on the potential use of biospecimens in research, the ownership, the need and preferred type of consent, and any possible obstacles to the use of those specimens in research (8 questions).

Arabic translation was performed byone of the investigators (A.A.H.) and was reviewed by the other investigator (M.A.H.). Research assistants were recruited from the School of Pharmacy at the University of Jordan and were trained in fundamental research ethics and on use of the questionnaire. After obtaining the institutional review board approval, a pilot phase was carried out in which the questionnaire was distributed to 20 adult patients attending the chemotherapy outpatient clinic.

\section{Data analysis}

The participants' demographic data and their responses to the questionnaire are presented as total counts and percentages. The participants' responses regarding donating and using their biospecimens in research were correlated with their demographic data and any previous participation in research using the chi-squared and Fisher exact tests. A significant $P$-value was determined at $\leq 0.05$. All analyses were performed using $S A S$, version 9.1. 


\section{Results}

\section{Patients' background characteristics}

The questionnaire was distributed to 205 participants (Table 1). There were 55 (26.8\%) males and 137 (66.8\%) females (missing data on 13 cases). The age ranged between 19 and 80 years old, with a mean of 48.5 years. The majority were of Jordanian nationality and resident in the capital city, Amman (66.3\%).

\section{Participation in medical research}

The first question explored any previous participation in medical research. A total of 48 patients (23.4\%) had participated in medical research, only 7 of whom (14.6\%) had participated previously in studies in which donation of blood samples or examination of tissue biopsies were requested. More than two-thirds of patients $(147,71.7 \%)$ had never participated previously in any medical research, since 93 of them (59.2\%) had never been approached by researchers. Humanitarian reasons such as helping other cancer patients and/ or benefiting society were listed as the main motivations for participation by 25/48 (52.1\%) and 133/147 (90.5\%) participants with and without previous research enrolment respectively.

\section{Patients' perceptions about use of biosamples}

The destination of the surplus blood samples withdrawn during routine clinical care was reasonably predicted. Of the participants 83 (40.5\%) thought that blood was disposed of immediately once the requested clinical tests were completed. The rest, however, did not have a clear idea about the destination of the surplus blood (Table 2). Comparable results were obtained for leftover/ excess tissue samples; only $23.9 \%$ were aware that the tissue blocks would routinely be archived in the pathology/ laboratory department at the Centre.

\begin{tabular}{|c|c|c|}
\hline Variable & No. & $\%$ \\
\hline \multicolumn{3}{|l|}{ Sex } \\
\hline Male & 55 & 26.8 \\
\hline Female & 137 & 66.8 \\
\hline Not stated & 13 & 6.3 \\
\hline \multicolumn{3}{|l|}{ Education level } \\
\hline Illiterate & 10 & 4.9 \\
\hline High school & 91 & 44.3 \\
\hline College & 34 & 16.6 \\
\hline University & 51 & 24.9 \\
\hline Postgraduate studies & 9 & 4.4 \\
\hline Not stated & 10 & 4.9 \\
\hline \multicolumn{3}{|l|}{ Marital status } \\
\hline Married & 160 & 78.0 \\
\hline Single & 15 & 7.3 \\
\hline Divorced & 9 & 4.4 \\
\hline Widowed & 10 & 4.9 \\
\hline Not stated & 11 & 5.4 \\
\hline \multicolumn{3}{|l|}{ Nationality } \\
\hline Jordanian & 178 & 86.8 \\
\hline Non-Jordanian & 9 & 4.4 \\
\hline Not stated & 18 & 8.8 \\
\hline \multicolumn{3}{|c|}{ Place of residence in Jordan $(n=178)$} \\
\hline Amman & 118 & 66.3 \\
\hline Outside Amman & 60 & 33.7 \\
\hline \multicolumn{3}{|c|}{ Previous participation in medical research } \\
\hline Yes & 48 & 23.4 \\
\hline No & 147 & 71.7 \\
\hline Not stated & 10 & 1.9 \\
\hline
\end{tabular}

Indeed, a similar percentage (23.4\%) thought that all tissue samples would be disposed of after the diagnosis was completed (Table 2).

The majority of participants (171, $83.3 \%$ ) declared that the physician or another member of the treating medical team had actually explained the procedure involving a tissue biopsy/resection and the indications for performing this procedure. However, 149 (72.7\%) confirmed that the procedural informed consent did not include any information about what happens to the tissue samples once diagnosis is completed.

When they were asked who they thought examined the tissue specimens after they had been removed for diagnostic purposes, half the patients (104, 50.7\%) knew that the laboratory doctor (pathologist) was the physician who examined the tissue.

Participants listed self-education through active searches in various available media (magazines, Internet, etc.), or through their previous experience, as the main sources of knowledge. Surprisingly, only $5.4 \%$ of participants considered the medical team as the source of information about blood samples and $7.4 \%$ about tissue samples. When several potential uses of surplus blood and archived tissue specimens were listed, comparable results were obtained 


\begin{tabular}{|c|c|c|c|c|}
\hline \multirow[t]{2}{*}{ Item $^{\mathrm{a}}$} & \multicolumn{2}{|c|}{ Blood samples } & \multicolumn{2}{|c|}{ Tissue samples } \\
\hline & No. & $\%$ & No. & $\%$ \\
\hline \multicolumn{5}{|l|}{ What do you think happens to the leftover tissue? } \\
\hline Thrown away immediately after the procedure & 83 & 40.5 & 48 & 23.4 \\
\hline Used to teach medical students about disease & 56 & 27.3 & 70 & 34.1 \\
\hline Used to test new drugs & 25 & 12.2 & 44 & 21.5 \\
\hline Preserved and kept (archived) & 21 & 10.2 & 49 & 23.9 \\
\hline Don't know & 35 & 17.1 & 31 & 15.1 \\
\hline \multicolumn{5}{|c|}{$\begin{array}{l}\text { If you were to decide on what happens to the leftover tissue, which of } \\
\text { the following would you agree to? }\end{array}$} \\
\hline Teaching medical students & 141 & 68.8 & 129 & 62.9 \\
\hline Medical research & 139 & 67.8 & 138 & 67.3 \\
\hline Diagnosing other diseases & 106 & 51.7 & 86 & 42.0 \\
\hline Training doctors & 78 & 38.0 & 78 & 38.0 \\
\hline Calibration of medical devices & 62 & 30.2 & 58 & 28.3 \\
\hline
\end{tabular}

${ }^{a}$ Patients could choose more than 1 response per question.

in both cases: 139 (67.8\%) and 138 (67.3\%) patients agreed on using the surplus blood and archived tissue specimens respectively in medical research (Table 2).

\section{Patients' perceptions of the ownership of biosamples}

The last part of the questionnaire focused on assessing patients' perceptions of the ownership of their samples and potential obstacles that might face researchers when dealing with biospecimens in research. The majority of patients believed that ownership lies within the framework of the medical body; 81 (39.5\%), 34 (16.6\%) and 14 (6.8\%) believed that the hospital, laboratory or surgeon owned the specimens, respectively. Only 55 (26.8\%) believed that the patient owned the specimens and $21(10.2 \%)$ did not know who claimed ownership. Most of the patients (196, 95.6\%) showed no interest in retrieving the blood/tissue specimens once clinical care was completed.

Interestingly, 170 (82.9\%) patients were willing to donate a blood sample primarily for research purposes, even if this was not driven by medical care. An explanatory note in this section of the questionnaire clearly stated that blood and tissue samples were not exhausted completely during the routine clinical work-up, and that tissue specimens were archived in the pathology department. The overwhelming majority (201, 98.0\%) accepted for their surplus/archived samples to be used in research if they consented, and most patients (166, $81.0 \%$ ) would consent to sending their samples for analysis to external international laboratories. Many participants (174, 84.9\%), however, were interested in knowing the results of the research tests on their specimens.

\section{Patients wish to give consent}

Two-thirds (139, 67.8\%) did not request to be consented each time their sampleswere used in research,i.e. agreed on a general opt-in approach. Patients who wanted to know the results of the research tests were significantly more inclined to require their consent being secured each time prior to using their samples $(P=0.02)$ (Table 3$)$, whereas those who did not object to their sample being sent to other laboratories were significantly less likely to request their consent being secured prior to any research study $(P=0.05)$ (Table 3$)$.
The impact of demographic variables (age, sex and level of education) and prior participation in research were tested against the patients' willingness to donate blood samples for research $(P$ $=0.90,0.91,0.94$ and 0.87 respectively) and their attitudes to use of leftover samples in research $(P=0.80,0.33,0.59$ and 0.27 respectively), the need to be consented each time leftover specimens are used $(P=0.17,0.33,0.067$ and 0.68 respectively) and sending exporting biospecimens abroad to international laboratories $(P=0.36,0.59,0.04$ and 0.40 respectively). None of the variables showed statistically significant results, except for education, which tended to affect the decision regarding the need to be consented each time specimens were used for research as well as accepting the export of specimens abroad.

\section{Discussion}

Our study offers an insight into the views of this sample of patients on the use of surplus blood and archived tissue specimens in research. The great majority of participants accepted the use of leftover samples in research if they have consented. Patents' age, sex, 


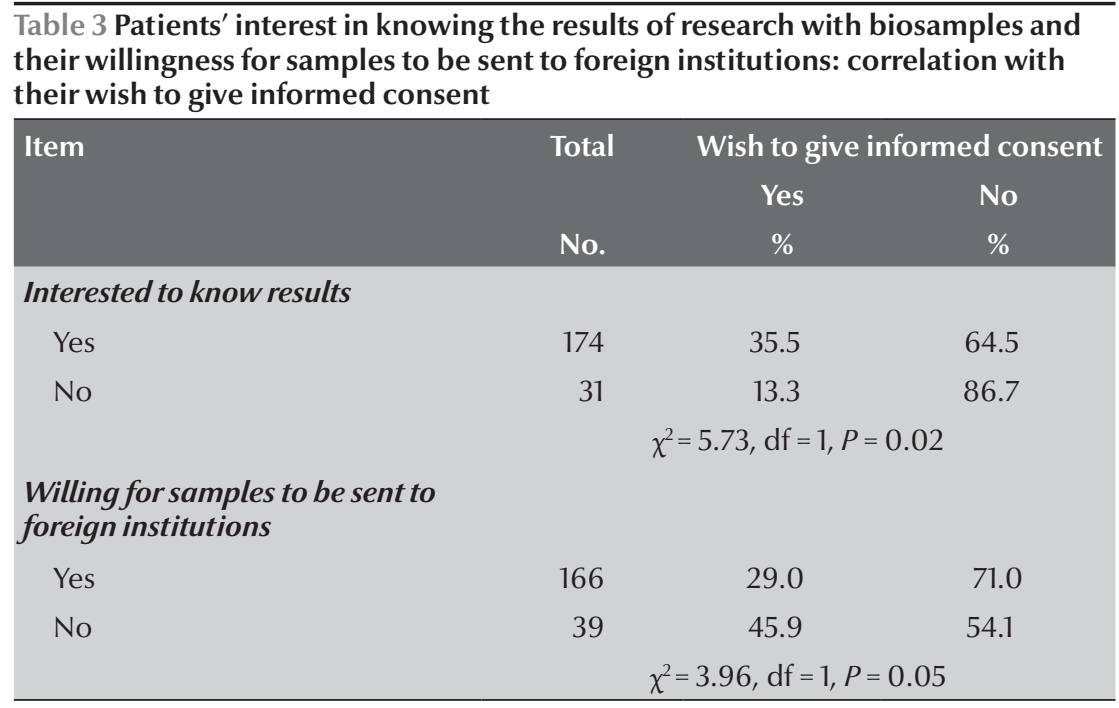

educational level and previous participation in research did not significantly affect their acceptance. The findings in our study are in accordance with other studies reported in the international literature (16-18). In other published studies agreement on the use of tissue in research was shown to be unaffected by patients' demographic characteristics or ethnicity and whether they were diseased or not $(17,19)$.

Respect for autonomy of research participants is the cornerstone of research ethics. Obtaining informed consent guarantees patients' autonomy. Whether an opt-in or opt-out, general or specific, consent is needed in biospecimen research is still being debated. A study on cancer patients in The Netherlands indicated that less than $5 \%$ of surveyed colon and breast carcinoma patients declined using their tissue in research. More patients (60\%) preferred an opt-out plus approach, in which active verbal information about the possibility to opt-out with all future research on their tissue was preferred to a one time general consent (11\%) (20). A focus group survey of the Japanese public indicated diverse attitudes towards the use of archived samples in research without consent. Their views ranged from a positive approval of the use of samples without prior consent, to reluctance to accept, to requesting a non-specific prior notice, up to wishing to have the power to opt-out and insistence on individual informed consent (21). A majority of Scottish people surveyed were positive about leftover blood being collected and stored for future research use, but they preferred an option for an open-ended consent (22). These same views were shared by a group of Finnish people surveyed (23). On the other hand, a Swedish study investigating public opinion on the use of biospecimens showed that the majority were willing to donate a sample for storage in biobanks for future research under a one-time general consent, subject to approval by ethics committees (24). Most of our participants indicated that they did not need to consent each time their samples were used in research if an initial consent at the time of collection of the samples was secured, i.e. they were satisfied with a general opt-in consent. Interestingly; these views were similar to what was reported by Ahram et al. in Jordan, in which $90 \%$ of the general population preferred an opt-in type of consent, more commonly of a general (75.2\%) rather than a specific (16.9\%) type (14). This gives credibility to our study since, although our sample was smaller and addressed the views of patients only, the conclusions were similar in both studies.
Ownership of the samples removed at the time of routine clinical care is another controversial point, with many hot debates between researchers, ethicists and the public, sometimes culminating in lawsuits (25). Ownership implies not only the physical possession of samples, but also the right to any potential benefits including financial gains and intellectual property. Ownership should be differentiated from custody, whereby specimens are held under the guardianship of the custodian, who might not be able to gain the rights to benefits. In a survey of post-surgery patients in the United Kingdom (UK) they listed the hospital (29.1\%), the patient (23.2\%) or the pathology department (19.7\%) as the owner of the samples (26); $15.0 \%$ believed that nobody can claim ownership rights, in accordance with the updated version of the Human Tissue Act in UK $(27,28)$. The majority of our surveyed participants thought that the various representatives of the medical body, i.e. the hospital, the pathology department and/ or the surgeon, had this ownership rights and only $10.2 \%$ thought that nobody should claim ownership. Although this is marginally less than the $15 \%$ reported by Bryant et al. (26), the difference could be explained on the basis of increased public awareness in the UK following adverse publicity in 2000 about tissue retention, for which public campaigns and legal inquiries were launched, and which has resulted in the amendments made to the Human Tissue Act (29).

Some limitations of the current study include the small number of participants recruited from a single institution. In addition, not all questionnaire items were completed by all patients. Despite this, the current study sheds light on the perception of our patients about the potential use of leftover biospecimens in research. Several recommendations emerged, including the need to update the Centre's procedural consent to include a clear statement on the potential use of archived tissue material in research, where an opt-in or opt-in plus approach 
could be adopted. We suggest that the medical team has to pursue a more active role in informing the patients about this vital issue, preferably during the process of consent. On the other hand, increasing public awareness about the value of human biospecimens in research through mass education and public campaigns was previously recommended by Ahram et al. (14). In Jordan, both studies could serve as a baseline and guidance for establishing nationwide guidelines.

\section{Acknowledgements}

The authors would like to thank Dr L. Zaru for her help in the statistical analysis and interpretation as well as valuable comments, Ms D. Al-Remawi for helping in the statistical analysis, Dr F. Attiga for the critical review of the manuscript and Dr J. Ro for final review and help with English correction.

The authors would also like to acknowledge the following students from the School of Pharmacy at Jordan University for helping in conducting the study: Z. Abdelmajeed, S. Al Hasan, D. Al Zobi, S. Anshasi, R. Eddeen, A. Fahhad, A. Khamees, H. Khamees and N. Shaheen.

We also thank Ms D. Khammash from the Medical School at the American University of Beirut for her help in data cleaning.

Funding: None.

Competing interests: None declared.

\section{References}

1. Landon MR. Ethics and policy perspectives on personalized medicine in the post-genomic era. J Biolaw Bus. 2005;8(3):2836. PMID:16459425

2. Cohen MC, Blakey S, Donn T, McGovern S, Parry L. An audit of parents'/guardians' wishes recorded after coronial autopsies in cases of sudden unexpected death in infancy: issues raised and future directions. Med Sci Law. 2009 Jul;49(3):179-84. PMID:19787989

3. Grizzle W, Grody WW, Noll WW, Sobel ME, Stass SA, Trainer $\mathrm{T}$, et al. Recommended policies for uses of human tissue in research, education, and quality control. Ad Hoc Committee on Stored Tissue, College of American Pathologists. Arch Pathol Lab Med. 1999 Apr;123(4):296-300. PMID:10320140

4. Ashcroft R. The ethics of reusing archived tissue for research. Neuropathol Appl Neurobiol. 2000 Oct;26(5):408-11. PMID:11054180

5. Upshur RE, Lavery JV, Tindana PO. Taking tissue seriously means taking communities seriously. BMC Med Ethics. 2007;8:11. PMID:17963497

6. Bathe OF, McGuire AL. The ethical use of existing samples for genome research. Genet Med. 2009 Oct;11(10):712-5. PMID:19745750

7. Truyers C, Kellen E, Arbyn M, Trommelmans L, Nys H, Hensen $\mathrm{K}$, et al. The use of human tissue in epidemiological research; ethical and legal considerations in two biobanks in Belgium. Med Health Care Philos. 2010 May;13(2):169-75. PMID:19936964

8. Schäfer SC, Lehr HA. A case study on the proper use of human tissues for biomedical research at an academic pathology institution in Switzerland. Pathobiology. 2007;74(4):259-63. PMID:17709969

9. Langat SK. Reuse of samples: ethical issues encountered by two institutional ethics review committees in Kenya. Bioethics. 2005 Oct;19(5-6):537-49. PMID:16425489

10. Maschke KJ, Murray TH. Ethical issues in tissue banking for research: the prospects and pitfalls of setting international standards. Theor Med Bioeth. 2004;25(2):143-55. PMID:15368751

11. Al-Qadire MM, Hammami MM, Abdulhameed HM, Al Gaai EA. Saudi views on consenting for research on medical records and leftover tissue samples. BMC Med Ethics. 2010;11:18. PMID:20955580

12. Abou-Zeid A, Silverman H, Shehata M, Shams M, Elshabrawy $M$, Hifnawy T, et al. Collection, storage and use of blood samples for future research: views of Egyptian patients expressed in a cross-sectional survey. J Med Ethics. 2010 Sep;36(9):53947. PMID:20663757
13. Tazzite A, Roky R, Avard D; Institut International de Recherche en Ethique Biomédicale. Les implications éthiques de la conservation des échantillons biologiques [The ethical implications of conserving biological samples]. J Int Bioethique. 2009 Sep;20(3):87-96, 150-1. PMID:20425942

14. Ahram M, Othman A, Shahrouri M. Public support and consent preference for biomedical research and biobanking in Jordan. Eur J Hum Genet. 2013 May;21(5):567-70. PMID:22968133

15. Ramahi I, Silverman H. Clinical research law in Jordan: an ethical analysis. Dev World Bioeth. 2009 Apr;9(1):26-33. PMID:18302540

16. Jack AL, Womack C. Why surgical patients do not donate tissue for commercial research: review of records. BMJ. 2003 Aug 2;327(7409):262. PMID:12896938

17. Chen DT, Rosenstein DL, Muthappan P, Hilsenbeck SG, Miller FG, Emanuel EJ, et al. Research with stored biological samples: what do research participants want? Arch Intern Med. 2005 Mar 28;165(6):652-5. PMID:15795341

18. Hoeyer K, Olofsson BO, Mjörndal T, Lynöe N. The ethics of research using biobanks: reason to question the importance attributed to informed consent. Arch Intern Med. 2005 Jan 10;165(1):97-100. PMID:15642883

19. Goodson ML, Vernon BG. A study of public opinion on the use of tissue samples from living subjects for clinical research. J Clin Pathol. 2004 Feb;57(2):135-8. PMID:14747435

20. Vermeulen E, Schmidt MK, Aaronson NK, Kuenen M, van der Valk P, Sietses C, et al. Opt-out plus, the patients' choice: preferences of cancer patients concerning information and consent regimen for future research with biological samples archived in the context of treatment. J Clin Pathol. 2009 Mar;62(3):275-8. PMID:19017681

21. Asai A, Ohnishi M, Nishigaki E, Sekimoto M, Fukuhara S, Fukui T. Attitudes of the Japanese public and doctors towards use of archived information and samples without informed consent: preliminary findings based on focus group interviews. BMC Med Ethics. 2002 Jan 9;3:E1. PMID:11825345

22. Treweek S, Doney A, Leiman D. Public attitudes to the storage of blood left over from routine general practice tests and its use in research. J Health Serv Res Policy. 2009 Jan;14(1):13-9. PMID:19103912

23. Tupasela A, Sihvo S, Snell K, Jallinoja P, Aro AR, Hemminki E. Attitudes towards biomedical use of tissue sample collections, consent, and biobanks among Finns. Scand J Public Health. 2010 Feb;38(1):46-52. PMID:19906772

24. Kettis-Lindblad A, Ring L, Viberth E, Hansson MG. Genetic research and donation of tissue samples to biobanks. What do 
potential sample donors in the Swedish general public think? Eur J Public Health. 2006 Aug;16(4):433-40. PMID:16207726

25. Charo RA. Body of research-ownership and use of human tissue. N Engl J Med. 2006 Oct 12;355(15):1517-9. PMID:17035644

26. Bryant RJ, Harrison RF, Start RD, Chetwood AS, Chesshire AM, Reed MW, et al. Ownership and uses of human tissue: what are the opinions of surgical in-patients? J Clin Pathol. 2008 Mar;61(3):322-6. PMID:18256118

27. Baum M. The use and abuse of human tissue: an analysis of the ethical issues raised by the proposed Human Tissue Act. Med Leg J. 2004;72(Pt 2):67-9. PMID:15239575
28. Angell E, Tarrant C, Dixon-Woods M. Research involving storage and use of human tissue: how did the Human Tissue Act 2004 affect decisions by research ethics committees? J Clin Pathol. 2009 Sep;62(9):825-9. PMID:19734481

29. Furness PN. Research using human tissues-a crisis of supply? J Pathol. 2001 Oct;195(3):277-84. PMID:11673823 